\title{
Correction to: Survival of midbrain dopamine neurons depends on the $\mathrm{BCl} 2$ factor $\mathrm{Mcl} 1$
}

Edward J. Robinson, Sebastian P. Aguiar, Willemieke M. Kouwenhoven, Dorinde S. Starmans, Lars von Oerthel, Marten P. Smidt and Lars P. van der Heide

(c) The Author(s) 2022

Cell Death Discovery (2022)8:102; https://doi.org/10.1038/s41420-022-00871-3

Correction to: Cell Death Discovery https://doi.org/10.1038/s41420-

018-0125-7, published online 21 November 2018

The original version of this article unfortunately contained mistakes in Figs. 1 and 2. Preliminary experiments with a new batch of neuro2a cells from atcc suggests that neuro2a cells behave similarly to the mn9d cells used in the manuscript (they are sensitive to $\mathrm{Mcl} 1$ inhibition with umi-77 and $\mathrm{Mcl} 1$ appears to have the same molecular weight as in mn9d cells). The corrected figures can be found below.

A.

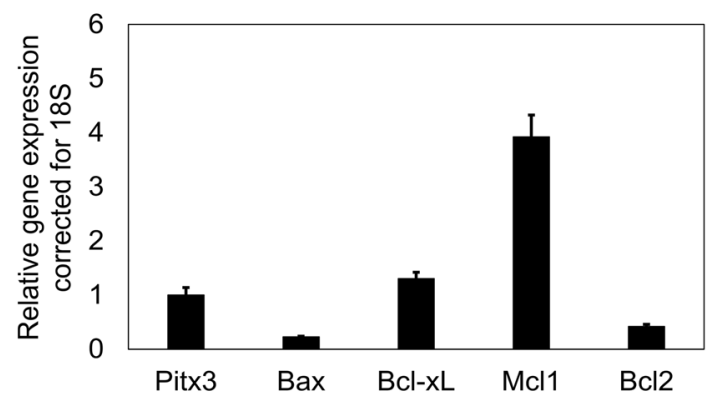

B.

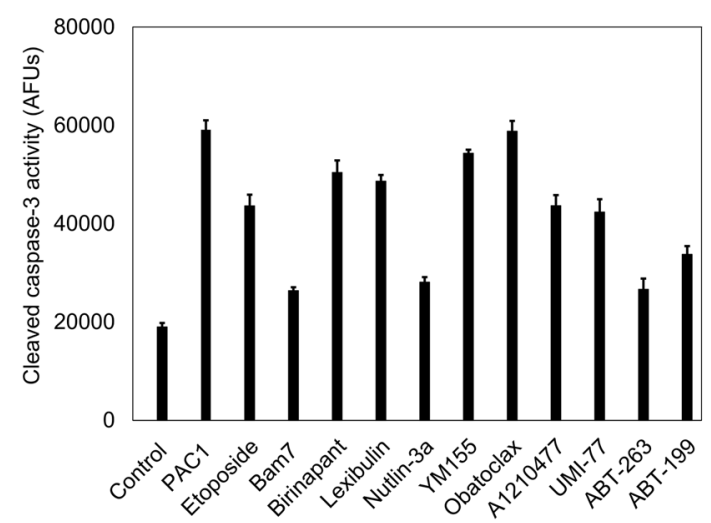


A.
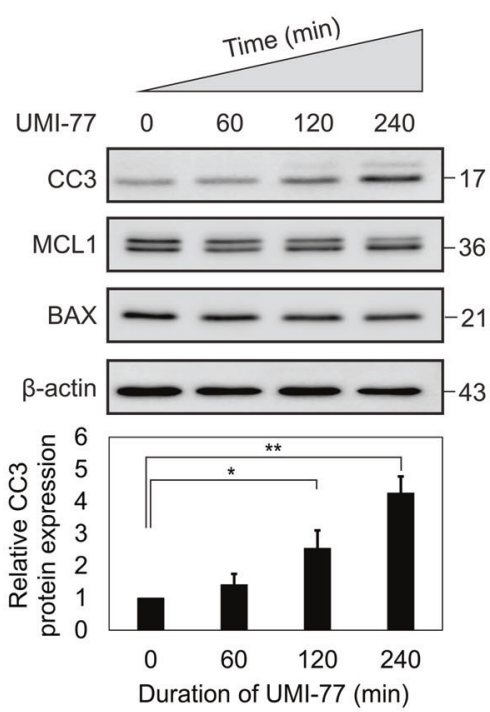

C.
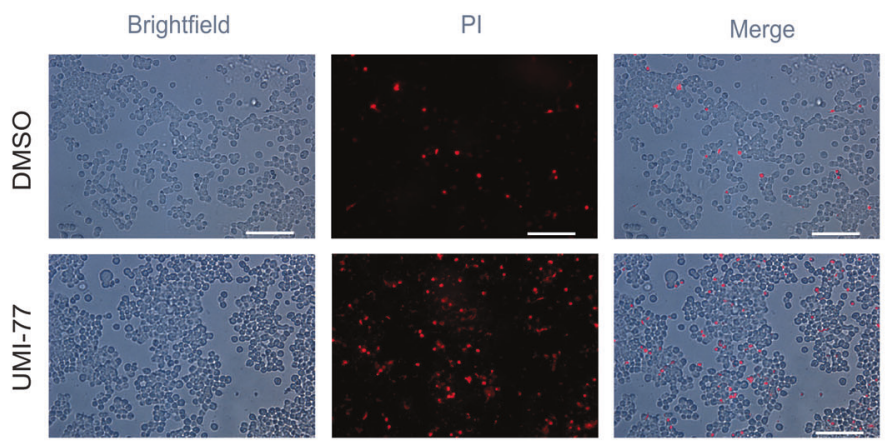

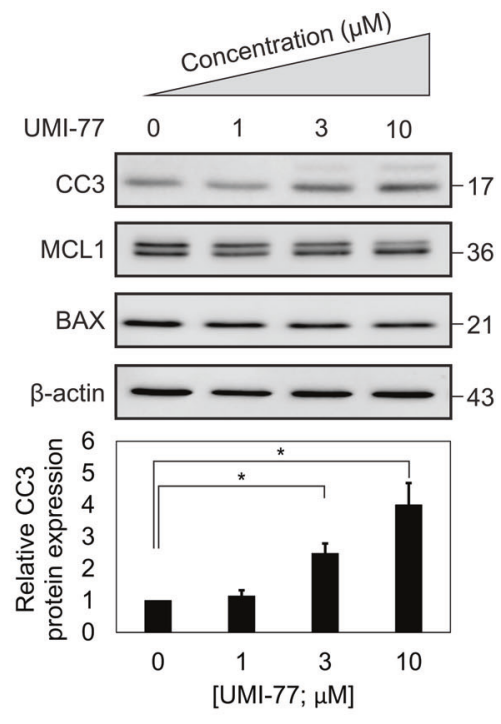

D.

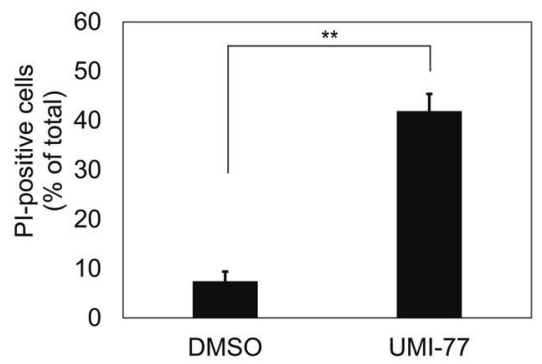

E.

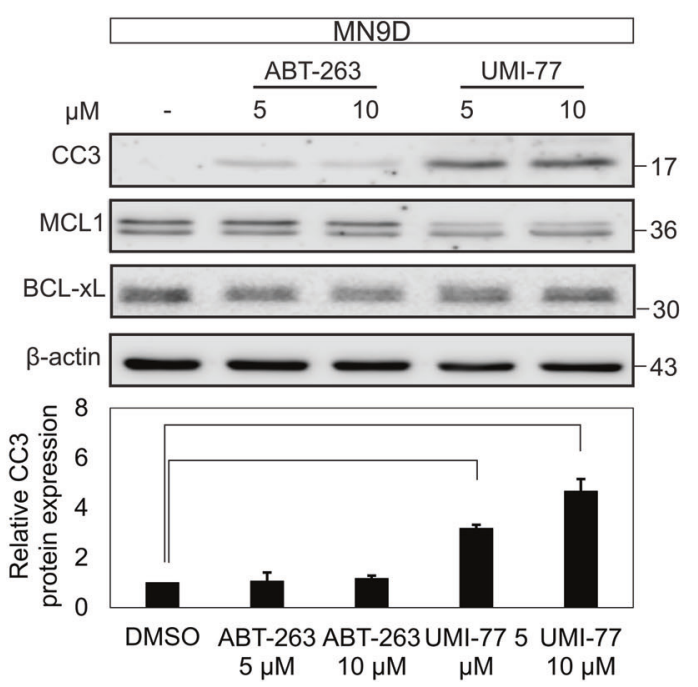

Open Access This article is licensed under a Creative Commons Attribution 4.0 International License, which permits use, sharing, adaptation, distribution and reproduction in any medium or format, as long as you give appropriate credit to the original author(s) and the source, provide a link to the Creative Commons license, and indicate if changes were made. The images or other third party material in this article are included in the article's Creative Commons license, unless indicated otherwise in a credit line to the material. If material is not included in the article's Creative Commons license and your intended use is not permitted by statutory regulation or exceeds the permitted use, you will need to obtain permission directly from the copyright holder. To view a copy of this license, visit http://creativecommons. org/licenses/by/4.0/.

(c) The Author(s) 2022 